\title{
C A E
}

\section{1.はじめに}

ハードウェアの低価格・高性能化を追い風に, CAEに 対する関心と期待が高まっており, 業界関連誌の特集や各 種のセミナーにおいて, 多くの導入事例や活用法が紹介さ れている。また，精密成形品" ${ }^{12}$ るいは大型成形品 ${ }^{21}$ への適 用事例を見て, CAEの導入を推進するケースも多くなっ ている，しかし，裾野が広がる一方で，「うまく使えない」, 「実測值と合わない」と頭を抱える担当者も少なくない. CAEを活用するためには多くの知識・経験を必要とされ ることが主因であるが(3), 要求・期待されている精度と 市販されている解析ソフトの精度との間に，隔たりがある ことも無視できない. 相変化を伴う複雑な近似式の確立と 膨大な演算処理が不可欠であることを考慮すれば，精度向 上のためには今後も多くの努力が必要と思われる. そこ で, 2001 年の学会発表や論文・解説記事の中から, 筆者 が特に興味を持ったものを紹介する。

\section{2. 射出成形 CAE}

比較的高精度な解析が可能になっている樹脂流動解析に 関連して，村田ら ${ }^{5), 6)}$ はベンチマークテストのための検証 結果（図 1，2）を報告している。ポリプロピレン・沉用 ポリスチレンの充填パターンだけでなく, 樹脂流量・ノズ ル温度や樹脂圧力の経時变化および温度分布が開示されて いることから，手持ちの解析ソフトで検証されることを勧 めたい．実際にベンチマークテストを行うためには，成形 条件の設定や計測方法について多くの検討が必要であり, その実施には多大な費用と時間が要求される. 今後も, こ のようなデータベースが公開されることによって, 容易に ベンチマークテストを行うことが可能になることを期待し たい. なお，射出開始時の応答性や圧力の切換え方法，あ るいはガスの排出抵抗の影響によって, 再現性に限界があ ることを考虑して解析結果との比較を行いたい。

近年, 普及が著しい三次元流動解析について, 井上ら ${ }^{7}$ は ランナー部で負の曲がり損失が生じることを報告している. 樹脂流動解析の三次元化によって, 従来は評価が困難で あった様々な流動現象に対して, 理論的な解釈が深まりつ つあることが感じられる.また, Ilinca ら ${ }^{81}$ は, 保厓・冷却工

\footnotetext{
* Otsuka, Hiroki

ポリプラスチックス侏 テクニカルサービスセンター 富士市窝島 973 (テ416-8533）

2002.5.13 受理
}

程を含めた三次元流動解析において,粘度・PvT モデル他 の影響を報告している.これまでに報告されている流動先 端の表現手法と併せて, Hele-Shaw 近似では表せなかった 現象を正確に予測できることを期待したい.ガスアシストや 発泡成形の分野に招いては三次元化が不可欠と思われるが, Haagh ら ${ }^{91}$ はリブ部における肉厚分布の検証結果を, 三谷 ${ }^{101}$ は偏肉パネルを用いた発泡流動の検証結果を報告している.

一方, 期待先行の感がある収縮・そり変形解析において は, 特に変形量が大きく問題となりやすい繊維強化材につ

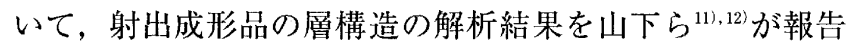
している.ガラス繊維で強化されたPA 6 について線膨張 係数の異方性を評価し, 流動・繊維配向解析結果を考慮し

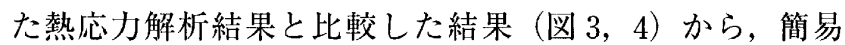
な 3 層構造の数值解析モデルでもそり変形挙動を定性的に 予测できること, ガラス絾維の充填割合によって配向層の 構造が変化することを立証している．また，山本 ${ }^{13}$ は粒子 シミュレーション法（図 5) が様々な充填材の運動解析に 有効であることを報告し（図 6), 野村ら ${ }^{14)}$ は同じく粒子シ ミュレーション法でガラス繊維の破断を予測している. 変 形に影響する層の分布と併せて，充填材の配向予測精度が 向上すれば，そり変形解析の精度が大幅に向上すると思わ れる。また, 藤田ら ${ }^{15}$ の力学的特性の予測や瀬戸ら ${ }^{16), 17)}$ の 物性值予測技術, Guo $5^{18)}$ の結晶化の影響に関する研究報 告も興味深く, これらの研究成果が $\mathrm{CAE}$ 解析へ適用され, 定量的な精度が向上することを期待したい。

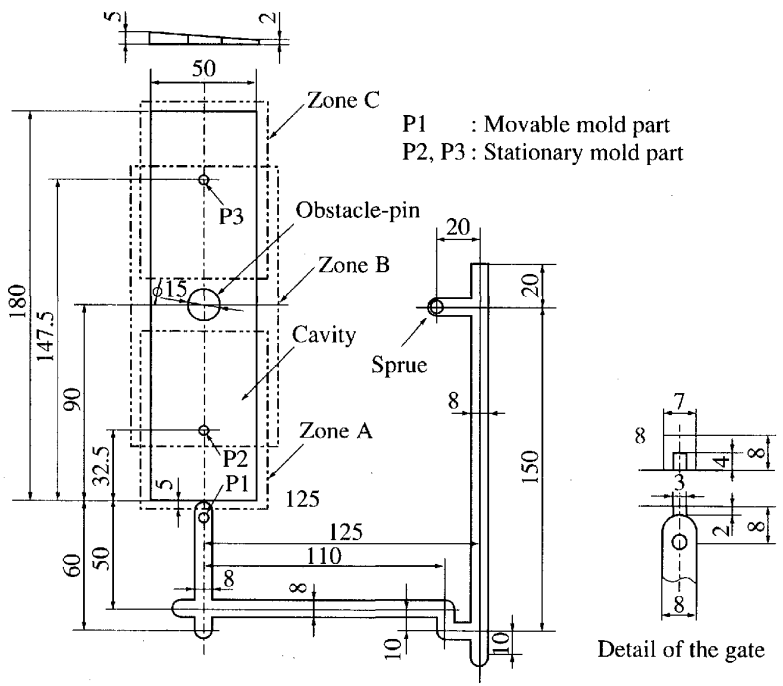

図 1 検証用傾斜肉厚・障害ピンキャビティの形状 ${ }^{5}$ 


\section{3。押出・ブロー CAE}

例年, 学会発表では射出成形 $\mathrm{CAE}$ を上回る勢いがある 押出関連の CAE は, 2001 年も多くの研究成果が報告され ている。スクリュ部の混練に関しては，木原ら ${ }^{19), 20)}$ がマー カーを用いた追跡実験の結果をもとに，二軸スクリュ押出 機内の分散混合過程の三次元シミュレーションプログラム を開発し，スクリュ形状の評価を行った結果を報告してい る.さらに，樹脂のほとんどが溶融すると考えられるニー ディングブロック部について，ミキシングエレメントの設 計への活用例 ${ }^{21}$ を報告している（図 7，8）。また，ピン付 スクリュの混練効果も三次元シミュレーションが可能に なっており ${ }^{222}$, これらの結果を考察することによって, 混 練のメカニズムがさらに解明されることを期待したい。ま た商業的には，有限体積法を拡張した動的マルチブロック

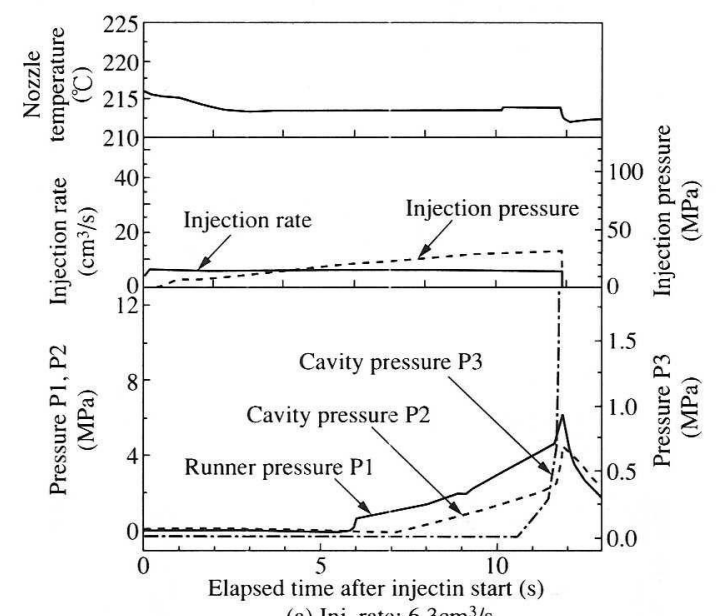

(a) Inj. rate: $6.3 \mathrm{~cm}^{3} / \mathrm{s}$

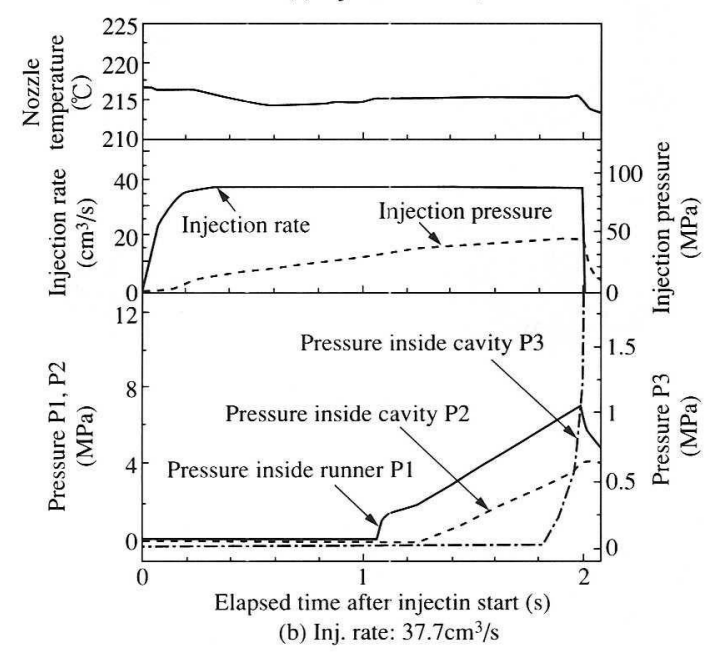

図 $2 P P$ の樹脂圧力測定結果 ${ }^{5}$

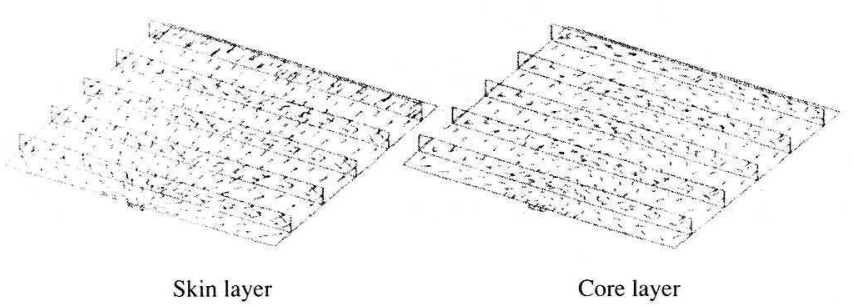

図 3 ガラス繊維の配向解析結果 ${ }^{11}$
法を応用した三次元の非定常熱流体解析機能を持つソフト が開発されている23. ダイ近辺に関しては, Tubagus ら ${ }^{241}$ が壁面のすべりの影響を考慮した三次元の数值解析を行い, ダイ設計に活用した例を報告している。また，岩田ら ${ }^{25} に$ よって, 付加粘性を導入した分割型有限要素法で円管ダイ スウェル流動解析を行い，その収束性を改善する独自の手 法も提案されている.ブロー成形の分野では, McCullough ら ${ }^{26)}$ が検証解析・実験を行って，ダイスウェルがパリソン の肉厚分布に及ぼす影響を報告している。また, Marckmann ${ }^{27}$ らは, 取手付ボトルの肉厚分布を AMR (Adaptive Mesh Refinement) 法で予測し, 実測值と比較 した結果を報告している（図 9). 実際の傾向をよく予測 している部分もある（図 10）ことから，ブローアップ前 後の肉厚分布の相関性に着目した研究が, 今後もさらに進 展することを期待したい.なお，ソフトウェアの最新動向 は業界誌の特集記事を参照していただきたい28,291.

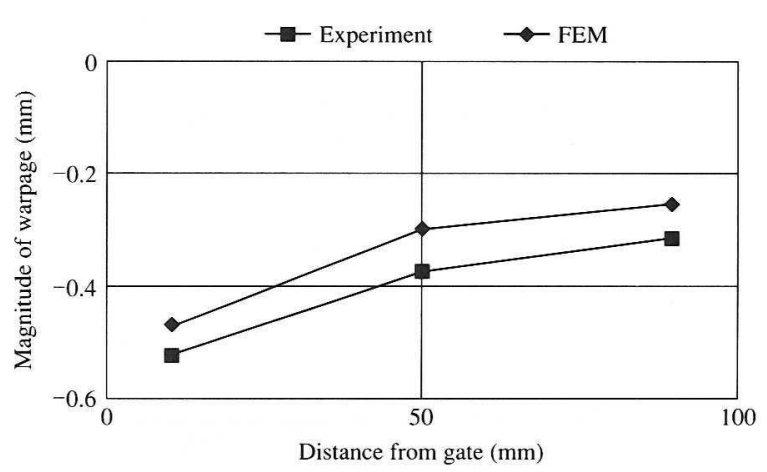

図 4 そり变形状態の比較結果 (平板 $3 \mathrm{mmt,}$, ブ $2 \mathrm{mmt}$, ガラス織維 $30 \mathrm{wt} \%$ ，流動直角方向） ${ }^{11}$ (a)

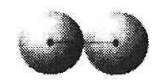

(b)

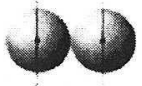

(c)

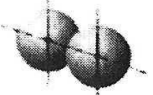

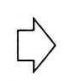
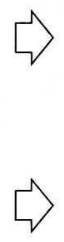
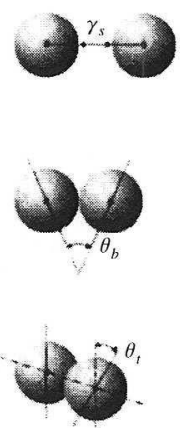

図 5 結合状態の模式図 ( (a) stretching, (b) bending, (c) twisting) ${ }^{13)}$

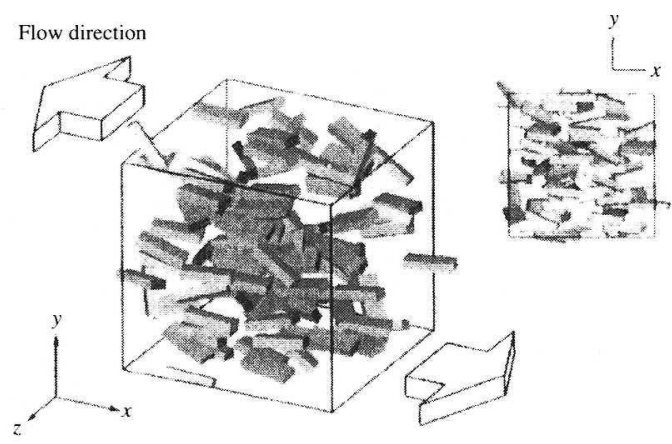

図 6 長方形粒子が分散したミクロ構造 (濃度 $5 \mathrm{vol} \%)^{13}$ 


\section{4. その他}

ここ数年, 金型設計や成形条件の最適化への CAE 活用 も多く提案されている. 樹脂流動解析は構造解析と比べて 計算時間が長くなりやすいことから，いかに計算回数を少 なくして最適解に到達するかが重要となるため, 高藤ら ${ }^{30)}$ や田村ら゙はは遺伝的アルゴリズムを用いた手法を提案して いる. ランナーのレイアウト変更と径の最適化(図 11，12） やランナー体積の考虑など，これまで勘と経験にたよって

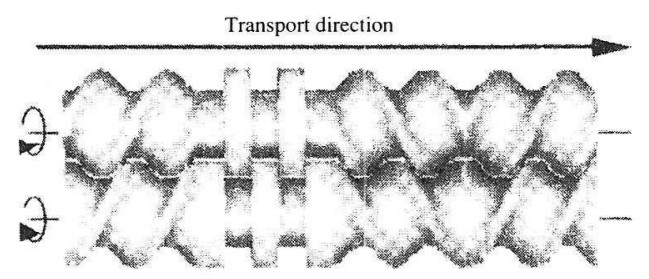

$\mathrm{Cl}(\mathrm{KB} / \mathrm{N}): \mathrm{DF} / \mathrm{R}+\mathrm{KB} / \mathrm{N}+\mathrm{DF} / \mathrm{L}+\mathrm{DF} / \mathrm{R}$

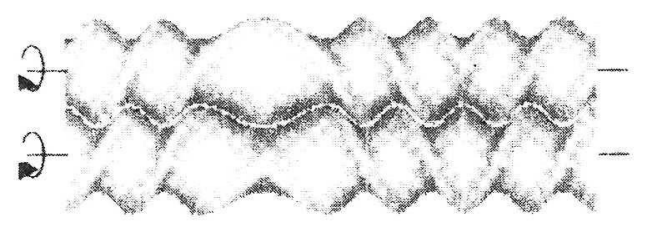

$\mathrm{C} 2(\mathrm{RO}): \mathrm{DF} / \mathrm{R}+\mathrm{ROTOR}+\mathrm{DF} / \mathrm{L}+\mathrm{DF} / \mathrm{R}$

図 7 スクリュ形状 ${ }^{21}$

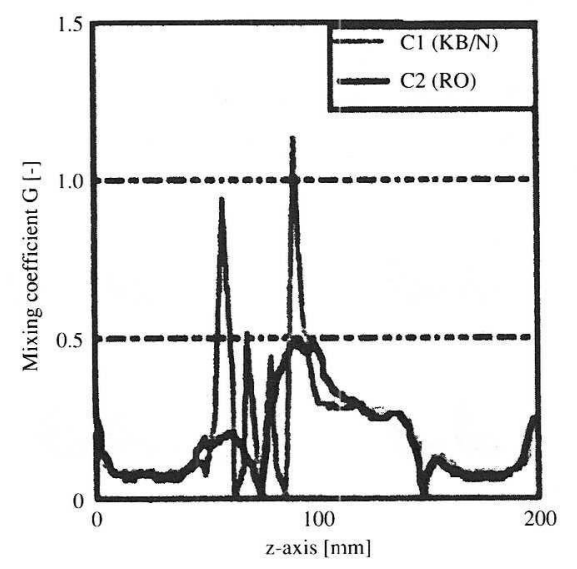

図 8 混合係数の計算結果例 ${ }^{211}$

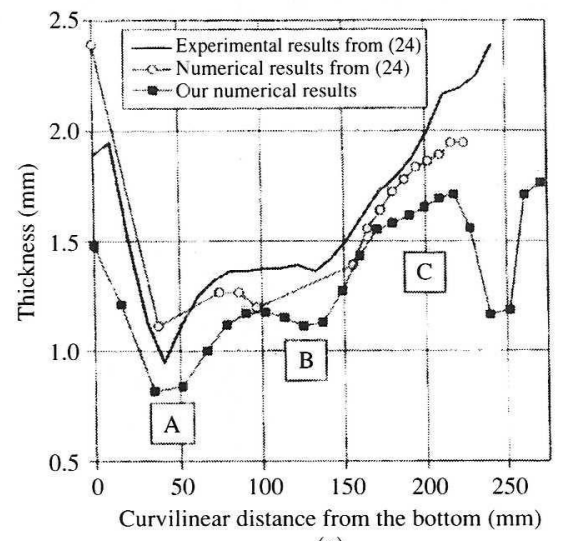

(a)
いた過程を，一定のアルゴリズムで代替している。解析担 当者の力量に左右される現状のアウトプットが，コン ピューター自身によってレベルアップできる点が興味深い。 商業的にも, 様々な最適化・サンプリング手法を選択でき る最適化ソフトと樹脂流動解析ソフトとを組み合わせるこ とによって，ゲート・ランナーレイアウトの最適化から ${ }^{322}$, 仮想成形と実成形を統合して成形条件の最適化までも可能 にする取り組み.33.34)が行われている. 現状の解析精度や費 用対効果を考慮すると，うまく適用できるケースは限られ る可能性があるものの, 今後の進展と普及について注意深 く見守っていきたい.

\section{5。おわりに}

「試作レスで量産型を起工する」,「コンカレントに開発 をすすめる」ことを目的に，「収縮率や変形量を定量的に 推定する」ためのツールとして, CAEが導入されるケー スは益々増大すると思われる. 解析ソフトの機能ばかりに 気を取られて, 解析精度の検証や基本的なアルゴリズムの 理解を㧍万そかにすることは是非とも避けたいものである. そのためにも,これから CAE に取り組む方や, 基本から 勉強し直したい方には, 連載講座「射出成形に及ぼす樹脂 流動特性の影響」吕をを一読されることを勧める。
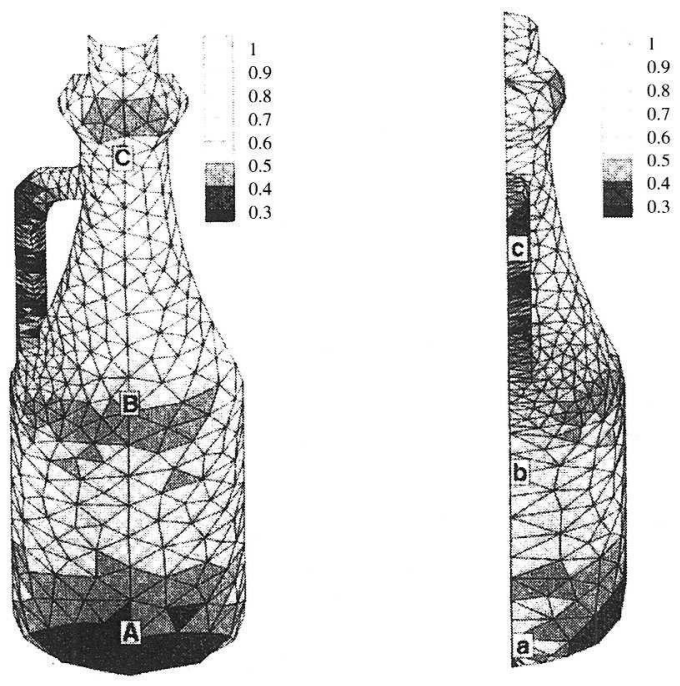

図 9 ブローアップ後の肉厚減少率分布 ${ }^{271}$

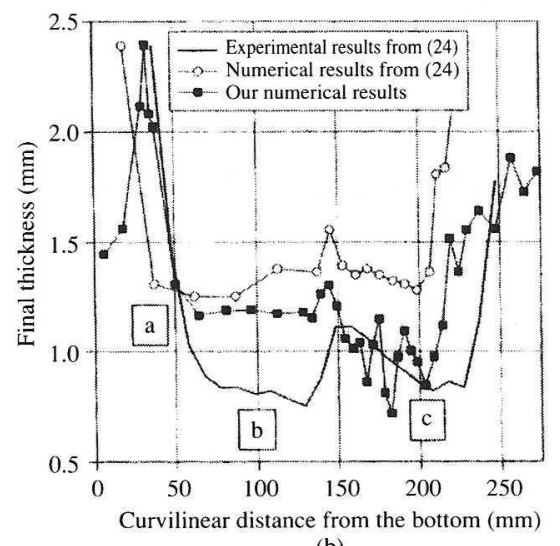

(b)

図 10 肉厚分布の比較検証結果 ${ }^{27)}$ 


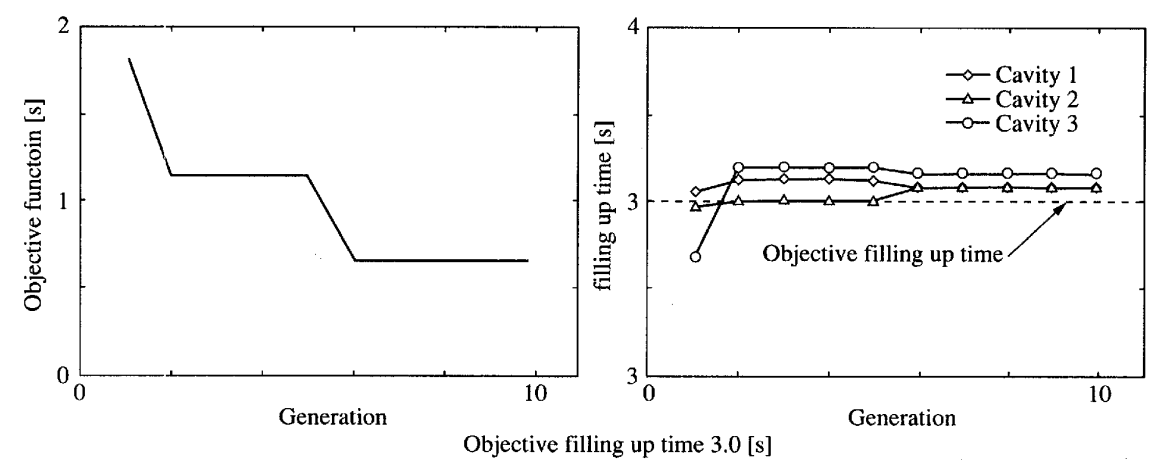

図 11 目的関数と充填時間の变移 ${ }^{30)}$
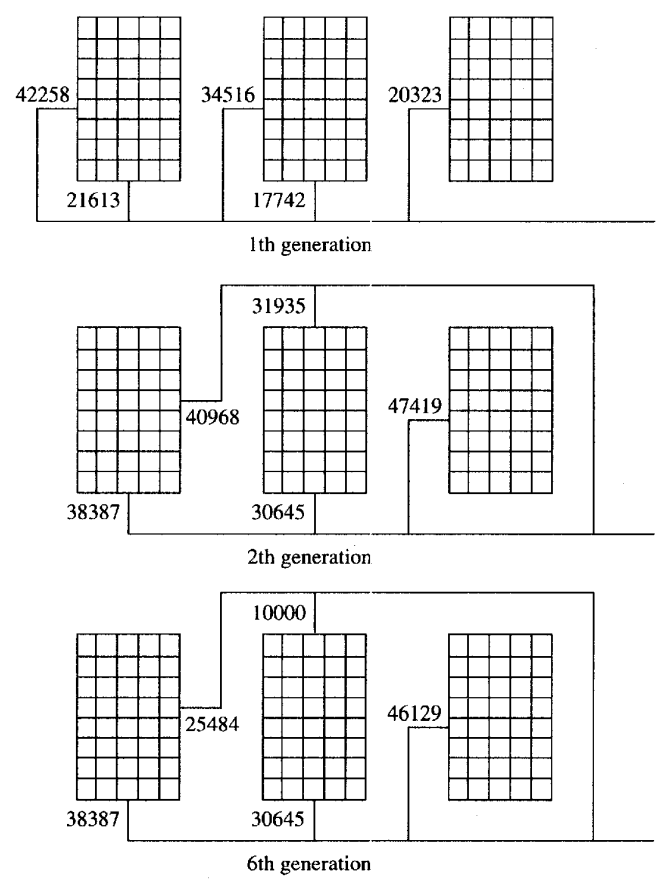

図 12 ゲート・ランナーの变更過程 ${ }^{30}$

\section{参 考 文 献}

1）佐藤弘次, 柳 秀一, 首藤義人, 植田祐治, 住田 真, 東野俊一：成形加工，13(1)，55（2001）

2) 荻野輝明, 澤江慎一, 菅原多加志: 型技術, 16 (7), $100(2001)$

3 ）吉野隆治：プラスチックスエージ，47(3)，115(2001)

4) 米川 太：プラスチックス, 52(3), 18 (2001)

5 ）村田泰彦, 横井秀俊：成形加工 '01，17（2001）

6) 村田泰彦, 横井秀俊: 成形加工シンポジア'01, 67 (2001)

7 ）井上良德，松岡孝明：成形加工，13(7)，490（2001）

8 ) Ilinca, F. and Hetu, J. -F. : International Polymer Processing, XVI (9) , 291 (2001)

$9)$ Haagh, G. A. A. V., Peters, G.W.M. and Van De Vosse, F. N. and Meijer, H. E. H. : Polymer Engineering and Science, 41 (3), 449 (2001)

10）三谷徽男：成形加工 '01，149（2001）

11）山下勝久, 野々村千里, 山田敏郎：成形加工, 13 (6), 200 (2001)

12）山下勝久, 野々村千里, 丹下章男, 山田敏郎：成形加 工’01，19（2001）
13) 山本 智: Journal of Society of Rheology, Japan, 29 (4), 185 (2001)

14）野村壮史, 山本 智, 松岡孝明: 成形加工' 01,21 (2001)

15）藤田章洋, 馬場文明, 石田 大, 仲井朝美, 潰田泰似： 成形加工，13(10)，700（2001）

16）瀬戸雅宏，山部 昌：成形加工’01，251（2001）

17）佐藤和人, 瀬戸雅宏, 山部 昌：成形加工シンポジア' 01, 221 (2001)

18) Guo, J. and Narh, K. A. : Polymer Engineering and Science, 41 (11), 1996 (2001)

19）木原伸一, 高山徽進, 山浦将智, 辻 哲治, 船津和守 : 成形加工 '01，37（2001）

20）石川 健, 天野太郎, 木原伸一, 船津和守: 成形加工 '01, 41 (2001)

21）山浦将智, 辻哲治, 木原伸一, 船津和守：成形加工シ ンポジア'01, 103 (2001)

22) Yao,W.G., Tanifuji,S., Takahashi, K. and Koyama, K. : Polymer Engineering and Science, 41 (6), 908 (2001)

23）吉川秀雄, 佐藤武志, 竹田 宏：“二軸スクリ工押出 機内樹脂流動解析システムの開発” 情報処理進行事業 協会・平成 10 年度情報ベンチャー事業化支援ソフト ウエア等開発事業に係る発表論文集 (2001)

24) Nouval Haedar TUBAGUS, 塩原真由美, 島田喜隆： 成形加工'01, 111 (2001)

25）岩田修一, 新垣 勉, 森 秀樹, 石川敏志, 和気 光 : 成形加工, $13(8), 523$ (2001)

26) Mccullough, M. D. and Heid, C. A. : Soc. Plast. Eng. Annu. Tech. Conf., 59(3), 3269 (2001)

27) Marckmann, G., Verron, E. and Peseux, B. : Polymer Engineering and Science, 41 (3), 426 (2001)

28）吉川秀雄 : プラスチックス, $52(3), 40$ (2001)

29）田中秀行, 田中 太：型技術，16(2)，45（2001）

30）高藤昭夫, 久保貴裕, 山根真一, 横山敦士, 演田泰似： 成形加工 '01，33（2001）

31）田村 圭, 横山敦士：成形加エシンポジア'01, 59 (2001)

32) 西浦光一：プラスチックスエージ，47(8), $129(2001)$

33）田中豊喜：計算工学, 6(2)，277（2001）

34）春日井賢治, 金岡雅俊：化学経済，48(4)，119(2001)

35）天野 修：プラスチックス, 52(6), 118（2001）他 